\title{
Acute pancreatitis in a COVID-19 patient in Brazil: a case report
}

\author{
Caroline Petersen da Costa Ferreira ${ }^{1,2^{*}}$, Kalynne Rodrigues Marques ${ }^{3}$, \\ Gustavo Henrique Ferreira de Mattos ${ }^{1}$ and Tércio de Campos $^{2}$
}

\begin{abstract}
Background: The consequences of the coronavirus disease 2019 pandemic have already exceeded 10 million infected and more than 560,000 deaths worldwide since its inception. Currently, it is known that the disease affects mainly the respiratory system; however, recent studies have shown an increase in the number of patients with manifestations in other systems, including gastrointestinal manifestations. There is a lack of literature regarding the development of acute pancreatitis as a complication of coronavirus disease 2019.

Case report: We report a case of acute pancreatitis in a white male patient with coronavirus disease 2019. A 35-yearold man (body mass index 31.5) had acute epigastric pain radiating to his back, dyspnea, nausea, and vomiting for 2 days. The patient was diagnosed with severe acute pancreatitis (AP)-APACHE II: 5, SOFA: 3, Marshall: 0; then he was transferred from ED to the semi-intensive care unit. He tested positive for severe acute respiratory syndrome coronavirus 2 on reverse transcription-polymerase chain reaction, and his chest computed tomography findings were compatible with coronavirus disease 2019. Treatment was based on bowel rest, fluid resuscitation, analgesia, and empiric antibiotic therapy. At day 12 , with resolution of abdominal pain and improvement of the respiratory condition, the patient was discharged.

Conclusion: Since there is still limited evidence of pancreatic involvement in severe acute respiratory syndrome coronavirus 2 infection, no definite conclusion can be made. Given the lack of other etiology, we consider the possibility that the patient's acute pancreatitis could be secondary to coronavirus disease 2019 infection, and we suggest investigation of pancreas-specific plasma amylase in patients with coronavirus disease 2019 and abdominal pain.
\end{abstract}

Keywords: Acute pancreatitis, Pancreatitis in COVID-19, Pancreatic involvement in COVID-19, Case report

\section{Background}

The coronavirus disease 2019 (COVID-19) pandemic affected more than 10 million people and caused more than 560,000 deaths, spreading across 213 countries worldwide, by early July 2020 [1]. COVID-19 is well established as a respiratory tract disease; however, recent studies have shown an increasing number of patients reporting gastrointestinal manifestations such

*Correspondence: cacapetersen@gmail.com

${ }^{1}$ Hospital Estadual de Francisco Morato Prof. Carlos da Silva Lacaz, Rod. Manoel Silverio Pinto, 125. Belém, Francisco Morato, SP, Brazil

Full list of author information is available at the end of the article as diarrhea, nausea, vomiting, and abdominal pain [2]. There is a lack of literature regarding the development of acute pancreatitis (AP) as a complication of COVID-19. In this paper, we report a case of acute acalculous pancreatitis in a COVID-19 patient.

The work has been reported in line with the CARE checklist, and it was approved by the local institutional review board.

\section{Case presentation}

A 35-year-old white man was admitted to the emergency department (ED). Two days before admission, he experienced a stabbing epigastric pain radiating to the back original author(s) and the source, provide a link to the Creative Commons licence, and indicate if changes were made. The images or other third party material in this article are included in the article's Creative Commons licence, unless indicated otherwise in a credit line to the material. If material is not included in the article's Creative Commons licence and your intended use is not permitted by statutory regulation or exceeds the permitted use, you will need to obtain permission directly from the copyright holder. To view a copy of this licence, visit http://creativecommons.org/licenses/by/4.0/. The Creative Commons Public Domain Dedication waiver (http://creativeco mmons.org/publicdomain/zero/1.0/) applies to the data made available in this article, unless otherwise stated in a credit line to the data. 
Table 1 Laboratory examinations

\begin{tabular}{|c|c|c|}
\hline Laboratory results & On admission & After 48 hours \\
\hline White blood cell count (per mm³) & 13.8 & 1.57 \\
\hline Band count & $5 \%$ & $20 \%$ \\
\hline Platelet count (per mm³) & 325.000 & 139.000 \\
\hline Hemoglobin (g/dL) & 16.2 & 15.8 \\
\hline Alanine aminotransferase (U/L) & 297 & 123 \\
\hline Aspartate aminotransferase (U/L) & 217 & 33 \\
\hline Total bilirubin (mg/dL) & 3.6 & 3.3 \\
\hline Direct bilirubin (mg/dL) & 4.6 & 3.3 \\
\hline Alkaline phosphatase (U/L) & 231 & 121 \\
\hline Urea (mg/dL) & 20 & 44 \\
\hline Creatinine (mg/dL) & 0.5 & 0.9 \\
\hline Amylase (U/L) & 1669 & \\
\hline C-reactive protein (mg/L) & 1.6 & 284 \\
\hline Triglycerides (mg/dL) & 225 & \\
\hline Calcium (mg/dL) & 8.6 & \\
\hline $\mathrm{Na}$ & 135 & 140 \\
\hline K & 4.5 & 4.3 \\
\hline
\end{tabular}

Table 2 Arterial blood gas analysis

\begin{tabular}{lll}
\hline $\begin{array}{l}\text { Arterial blood gas } \\
\text { analysis }\end{array}$ & On admission & On the sixth day \\
\hline $\mathrm{pH}$ & 7.37 & 7.43 \\
$\mathrm{pCO}_{2}$ & 33 & 29 \\
$\mathrm{pO}_{2}$ & 76 & 64 \\
$\mathrm{HCO}_{3}$ & 20.7 & 21.7 \\
Base excess & -5.3 & -4.0 \\
Saturation & $95 \%$ & $93 \%$ \\
\hline
\end{tabular}

and dyspnea as well as nausea and vomiting. Comorbidities included obesity [body mass index (BMI): 31.5 ] and gastritis treated with omeprazole. He denied allergies and alcohol intake, and did not smoke. He worked as a radiology technician, he had never undergone surgery, and had no health problems in the family.

At admission, the patient had tachycardia (126 beats per minute), normal blood pressure $(121 \times 95 \mathrm{mmHg})$, dehydration $(+/ 4+)$, jaundice $(+/ 4+)$, and oxygen saturation $\left(\mathrm{SaO}_{2}\right)$ of $95 \%$ on room air. Severe epigastric tenderness was noted. There were no other findings on physical and neurological examination. Admission laboratory findings are summarized in Tables 1 and 2. Chest and abdomen computed tomography (CT) both showed multifocal bilateral ground-glass opacities (Fig. 1) and pancreas with increased dimensions and densification of adipose planes in its body and tail, thickening of the left anterior pararenal fascia, minimal amount of free peripancreatic fluid, and normal gallbladder and biliary tract. He had two previous abdominal ultrasounds showing a normal gallbladder.

The patient was diagnosed with severe AP classified as APACHE II: 5, SOFA: 3, Marshall: 0; then he was transferred from ED to the semi-intensive care unit. Initially, treatment was based on bowel rest, fluid resuscitation, and analgesia with morphine. At day 2, enteral diet was introduced using a post papilla nasoenteral tube. Later, empiric antibiotic treatment for the risk of bacterial pneumonia was started. The patient tested positive for severe acute respiratory syndrome coronavirus 2 (SARS$\mathrm{CoV}-2)$ on reverse transcription-polymerase chain reaction (RT-PCR); then he was transferred to intensive care unit (ICU). A new abdominal ultrasound corroborated a normal gallbladder and biliary tract. Acute hypoxic respiratory failure progressed, and the patient required high-flow oxygen supplementation. Supportive therapy was continued, and, at day 7 , oral diet was introduced and the patient showed a gradual resolution of his pulmonary symptoms. The patient spent 9 days in the ICU

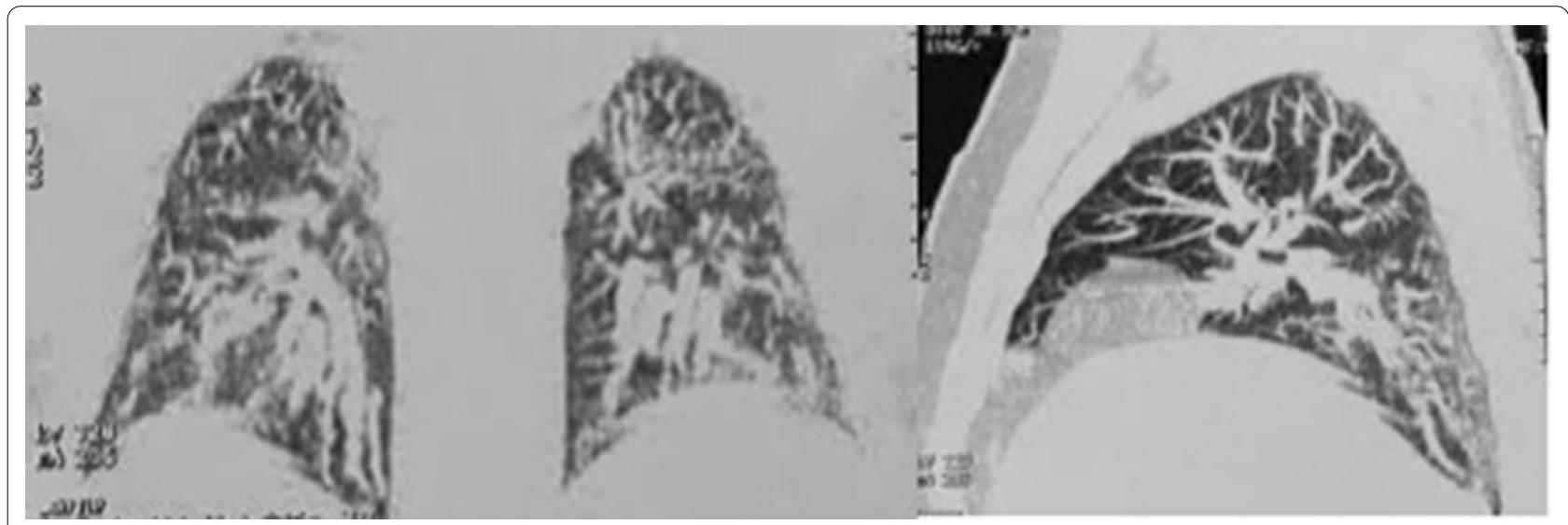

Fig. 1 Chest tomography showing multifocal bilateral ground-glass opacities 
and was discharged from the hospital 12 days after admission. One month after discharge, the patient was recovering at home, without symptoms. As of the last update, 6 months after discharge, he was fully recovered, without any new AP episode.

\section{Discussion}

The group of coronaviruses $(\mathrm{CoV})$ is a group of singlestranded ribonucleic acid (RNA) viruses, belonging to the subfamily Orthocoronavirinae and family Coronaviridae, which infect humans and animals. Only the alpha and beta genera can infect humans, with symptoms often associated with a cold [3]. The first epidemic caused by $\mathrm{CoV}$ occurred in 2002 in Guangdon, China, by SARS-CoV-1 causing severe acute respiratory syndrome (SARS) with 916 deaths in 29 countries. Then, in 2012, Middle East respiratory syndrome (MERS) caused by a $\mathrm{CoV}$ was identified with 858 deaths. In 2019, there were reports of symptomatic individuals who had contact with SARS-CoV-2 present in bats from a wet market in Wuhan, China, being responsible for COVID-19. In the three episodes, there was zoonotic overflow, aggravated by the cultural practices and fragile health laws in those regions $[4,5]$.

Classical symptoms include fever, cough, and fatigue in addition to sputum, hemoptysis, diarrhea, headache, and lymphopenia. Unique features include targeting of the lower airways and RNAemia, combined with incidence of ground-glass opacity and acute cardiac injury [6].

$\mathrm{AP}$ is a disease caused by an abnormality in the activation of pancreatic enzymes with the release of inflammatory mediators, which can compromise peripancreatic tissues and other organs [7]. AP has a multitude of potential causes, including gallstones, alcohol, hypertriglyceridemia, trauma, post-endoscopic retrograde cholangiopancreatography (ERCP), hypercalcemia, medications, anatomic anomalies, and infections or toxins. Known viral causes of pancreatitis include mumps, coxsackievirus, hepatitis B, cytomegalovirus, varicella zoster, herpes simplex, and human immunodeficiency virus [8].

Up to $10 \%$ of AP is thought to have an infectious etiology through an immune-mediated inflammatory response, most notably mumps and coxsackie B viruses [9]. However, the pathophysiological mechanism by which a virus, such as the coronavirus, could cause acute pancreatitis is not clear. The main explanations suggest a cytopathic effect of viral replication, or the virus-induced immune response itself [10]. In this patient, other causes of AP were excluded (including alcohol, biliary obstruction/gallstones, anatomic anomalies, drugs, trauma, hypertriglyceridemia, hypercalcemia, and hypotension).

This case demonstrates the possibility of pancreatic injury in patients with COVID-19, in line with previously reported similar cases. A literature review was performed in April 2020 with the following descriptors: acute pancreatitis and COVID-19 in PubMed database, and eight cases were found: two cases in the same family [11], one case in a pregnant woman [12], one in a child [13], one in a woman in Iran [14], one in a woman in Paris [15], one in a woman in the UK [16], and one in a man in Romania [17]. Among these eight cases, only one case occurred in an adult man [17], as in the case described in this report.

A new literature review was carried out in May 2021 with the following descriptors: acute pancreatitis and COVID-19 in PubMed database, and about 90 papers showed up. Of these, 54 were case or series reports. One study shows the point prevalence, risk factors, and outcomes of 32 hospitalized patients with COVID-19 presenting with acute pancreatitis in a large health system and compares outcomes of pancreatitis in patients without COVID-19 [18]. Another one analyzed the clinical profiles of 17 patients with COVID-19 and acute pancreatitis [19]. Most of the other studies were about the increase of amylase and lipase without pancreatitis or about the possible relationships between these two entities. Further large studies are needed to confirm these findings. A better understanding of the relationship between AP and COVID-19 will guide clinicians on early management strategies and focus medical resources toward those patients at risk for worse outcomes.

The increased interest in studying the relationship between AP and COVID-19 suggests a yet to be delineated complex interaction between them.

It is important to note that patients infected with COVID-19 can present the less common gastrointestinal symptoms without early respiratory symptoms. This highlights the need for appropriate personal protective equipment for providers, even when COVID-19 is not initially on the differential diagnosis.

\section{Conclusion}

Given the lack of other etiology, we consider the possibility that the patient's acute pancreatitis could be secondary to COVID-19 infection, and we suggest investigation of pancreas-specific plasma amylase in patients with COVID-19 and abdominal pain.

\section{Abbreviations}

CT: Computed tomography; AP: Acute pancreatitis; CoV: Coronaviruses; ERCP: Endoscopic retrograde cholangiopancreatography; ICU: Intensive care unit; SARS: Severe acute respiratory syndrome.

\section{Acknowledgements}

We would like to thank the patient for allowing the publication of the case and our colleagues from these institutions. We also like to thank Melissa Bona Nascimento for helping us with English. And we would also like to thank Melissa Bona Nascimento for helping us with English. 


\section{Authors' contributions}

CPCF and GHFM were the surgeons who treated the patient during his hospitalization and recovery. CPCF was responsible for collecting the data. KRM reunited the information of the patient, and TC was responsible for editing. CPCF was a major contributor in writing the manuscript. All authors read and approved the final manuscript.

\section{Funding}

Not applicable.

\section{Availability of data and materials}

Not applicable.

\section{Declarations}

\section{Ethics approval and consent to participate}

The technical board of Francisco Morato State Hospital-Lacaz approved this case report. A copy of the written liberation is available for review by the Editor-in-Chief of this journal. The patient gave written informed consent to publish this case.

\section{Consent to participate}

Written informed consent was obtained from the patient for publication of this case report and any accompanying images. A copy of the written consent is available for review by the Editor-in-Chief of this journal.

\section{Competing interests}

The authors declare that they have no competing interests.

\section{Author details}

${ }^{1}$ Hospital Estadual de Francisco Morato Prof. Carlos da Silva Lacaz, Rod. Manoel Silverio Pinto, 125. Belém, Francisco Morato, SP, Brazil. ${ }^{2}$ rrmandade da Santa Casa de Misericórdia de São Paulo, Rua Cesário Mota Junior 112. Vila Buarque São Paulo, SP, Brazil. ${ }^{3}$ Centro Universitário Uninovafapi, Rua Vitorino Orthiges Fernandes, 6123, Planalto Uruguai, Teresina, PI, Brazil.

Received: 31 July 2020 Accepted: 17 May 2021

Published online: 26 October 2021

\section{References}

1. COVID-19 coronavirus a pandemic. https://www.worldometers.info/ coronavirus/. Accessed 17 July 2020.

2. Patel KP, Patel PA, Vunnam RR, Hewlett AT, Jain R, Jing R, et al. Gastrointestinal, hepatobiliary, and pancreatic manifestations of COVID-19. J Clin Virol. 2020;128:104386. https://doi.org/10.1016/j.jcv.2020.104386.

3. Cui J, Li F, Shi ZL. Origin and evolution of pathogenic coronaviruses. Nat Rev Microbiol. 2019;17(3):181-92. https://doi.org/10.1038/ s41579-018-0118-9.

4. Chu DKW, Poon LLM, Gomaa MM, Shehata MM, Perera RAPM, Zeid DA, et al. Coronaviruses in dromedary. 2014;20(6):1049-53.
5. Gorbalenya AE, Snijder EJ, Spaan WJM. Severe acute respiratory syndrome coronavirus phylogeny: toward consensus. J Virol. 2004;78(15):7863-6.

6. Huang $C$, Wang Y, Li X, Ren L, Zhao J, Hu Y, et al. Clinical features of patients infected with 2019 novel coronavirus in Wuhan, China. Lancet. 2020;395(10223):497-506. https://doi.org/10.1016/S0140-6736(20) 30183-5.

7. Banks PA, Freeman ML, Fass R, Baroni DS, Mutlu EA, Bernstein DE, et al. Practice guidelines in acute pancreatitis. Am J Gastroenterol. 2006:101(10):2379-400.

8. Parenti DM, Steinberg W, Kang P. Infectious causes of acute pancreatitis. Pancreas. 1996:13(4):356-71.

9. Rawla P, Bandaru SS, Vellipuram AR. Review of infectious etiology of acute pancreatitis. Gastroenterol Res. 2017;10(3):153-8. https://doi.org/10. 14740/gr858w.

10. Aloysius MM, Thatti A, Gupta A, Sharma N, Bansal P, Goyal H. COVID-19 presenting as acute pancreatitis. Pancreatology. 2020. https://doi.org/10. 1016/j.pan.2020.05.003

11. Hadi A, Werge M, Kristiansen KT, Pedersen UG, Karstensen JG, Novovic S, Gluud LL. Coronavirus disease-19 (COVID-19) associated with severe acute pancreatitis: case report on three family members. Pancreatology. 2020;19:19-21. https://doi.org/10.1016/j.pan.2020.04.021.

12. Rabice SR, Altshuler PC, Bovet C, Sullivan C, Gagnon AJ. COVID-19 infection presenting as pancreatitis in a pregnant woman: a case report. Case Rep Women's Health. 2020;27:e00228. https://doi.org/10.1016/j.crwh. 2020.e00228.

13. Alloway BC, Yaeger SK, Mazzaccaro RJ, Villalobos T, Hardy SG. Suspected case of COVID-19 associated pancreatitis in a child. Radiol Case Rep. 2020;15(8):1309-12. https://doi.org/10.1016/j.radcr.2020.06.009.

14. Karimzadeh S, Manzuri A, Ebrahimi M, Huy NT. COVID-19 presenting as acute pancreatitis: lessons from a patient in Iran. Pancreatology. 2020. https://doi.org/10.1016/j.pan.2020.06.003.

15. Miao Y, Lidove $O$, Mauhin W. First case of acute pancreatitis related to SARS-CoV-2 infection. Br J Surg. 2020;107(8):e270. https://doi.org/10. 1002/bjs.11741.

16. Anand ER, Major $C$, Pickering $O$, Nelson M. Acute pancreatitis in a COVID19 patient. Br J Surg. 2020;107(7):e182. https://doi.org/10.1002/bjs.11657.

17. Pinte $L$, Baicus $C$. Pancreatic involvement in SARS-CoV-2: case report and living review. J Gastrointest Liver Dis. 2020;29(2):275-6. https://doi.org/10. 15403/jgld-2618.

18. Inamdar S, Benias PC, Liu Y, Sejpal DV, Satapathy SK, Trindade AJ. Prevalence, risk factors, and outcomes of hospitalized patients with coronavirus disease 2019 presenting as acute pancreatitis. Gastroenterology. 2020;159(6):2226-2228.e2. https://doi.org/10.1053/j.gastro.2020.08.044.

19. Kumar V. Clinical course and outcome among patients with acute pancreatitis and COVID-19. Eur J Gastroenterol Hepatol. 2021;33(5):695-700.

\section{Publisher's Note}

Springer Nature remains neutral with regard to jurisdictional claims in published maps and institutional affiliations.

Ready to submit your research? Choose BMC and benefit from

- fast, convenient online submission

- thorough peer review by experienced researchers in your field

- rapid publication on acceptance

- support for research data, including large and complex data types

- gold Open Access which fosters wider collaboration and increased citations

- maximum visibility for your research: over 100M website views per year

At $\mathrm{BMC}$, research is always in progress.

Learn more biomedcentral.com/submissions 